\title{
The in-bond assembly industry and technical change
}

\section{Rudolf M. Buitelaar}

Industrial and Technological Development Unit,

ECLAC Division of Production, Productivity and Management.

\section{Ramón Padilla} Ruth Urrutia

Staff members of the

Industry Unit,

ECLAC Subregional

Headquarters in Mexico.
This article analyses the export offensive made by Mexico, Central America and some Caribbean countries since the mid-1980s. Notwithstanding the differences between them, in all the countries in question this offensive has been aimed mainly at the United States market, has been stimulated by import tariff privileges and other incentives, and has been based on poorly-paid assembly operations: i.e., it involves the in-bond assembly or "maquila" industries. This study seeks to determine whether these industries contribute to local technological development. The answer, based on a questionnaire sent to 75 maquila firms in six countries, must be "yes". The maquila industry uses production techniques close to the best international practices -something matched only in a very few domestic manufacturing firms - and it helps to train human resources and introduce modern concepts of organization and management. Moreover, it makes intensive use of unskilled labour. Consequently, in order to progress towards sustainable development with social equity it would appear to be necessary to turn the maquila industry into an increasingly competitive activity by increasing its productivity and the added value of its products. The evolution of maquila industries in the direction of activities using a more highly skilled labour force is perfectly possible, as the case of Mexico shows, and it will become unavoidable when pressures on the labour market cause real wages to rise, as in Costa Rica. This will not happen automatically, however, and even less so in countries that lack institutions to support that process. 


\section{I}

\section{Introduction}

The export structure and performance of Mexico, Central America and some Caribbean countries has changed greatly over the past two decades. These countries used to depend heavily on exports of primary products, but began to face declining market shares in that activity. Today, they mainly export manufactured products and are rapidly gaining market shares. Apparently, this is exactly what conventional wisdom would suggest such countries should do in order to achieve economic development: increase their participation in international trade and change the product composition of their exports. Indeed, ECLAC has formulated policy statements in this sense (ECLAC, 1990).

But is this particular kind of export drive a good engine for development? ECLAC distinguishes various different ways for a country to expand exports (ECLAC, 1990), and some may be more conducive to development than others. International competitiveness can be achieved by constantly lowering real wages, at the expense of the environment, or via government subsidies to firms, at the cost of increasing fiscal deficits. Exports based on one of those factors may not lead to sustainable development. The late Fernando Fajnzylber, who coordinated the ECLAC study in question, labeled these forms as "spurious" competitiveness. On the other hand, international competitiveness can be based on increasing productivity, which requires continuous technical progress. The same author considered technical change to be the only "authentic" source of competitiveness, and the most conducive to sustainable development. The 1990 ECLAC propositions therefore aimed at increasing competitiveness through technical change.

Let us consider the export drive carried out since the mid-1980s by the countries mentioned above. Naturally, there are conspicuous differences between Mexico on the one hand, and the Central American and Caribbean countries on the other. This paper will

$\square$ This paper is based on ECLAC (1998) and is a revision of a paper presented at the 21st Conference of the Latin American Studies Association, Chicago, 1998. discuss those differences at some length. Nevertheless, it is true for all these countries that the export drive has been i) chiefly oriented towards the United States market; ii) stimulated by import tariff privileges and local tax exemptions and other incentives, and iii) it has been based on low-wage assembly-type operations: what have come to be known as "maquila industries", the definition of which is not very clear-cut. At all events, the last two points seem to fit closely the description of "spurious competitiveness".

To dismiss the export success of these countries as being based on "spurious competitiveness" and "less conducive to development" would be too rash a conclusion, however. Does the maquila industry contribute at all to technological progress? Is there technical change in the maquila industry? If it is not, as yet, a sign of "authentic" competitiveness, could it perhaps lead to it? These are the questions this paper seeks to answer.

A questionnaire was applied to some 75 maquiladora firms in six countries, ${ }^{1}$ on the basis of which we are able to describe in some detail the technology transfer and learning processes in maquila firms. Differences between the Mexican experience and that in the other five countries became apparent. Also, differences between firms with capital of different national origin were observed. In all, we conclude that there is (albeit quite limited) some form of technology transfer and an upgrading of local productive capacities through maquila. This aspect has been rather neglected in the development strategies of those countries, in which maquila is seen mainly as an employment generating device and to some extent also as a foreign exchange earner. It has hardly been considered as a source for the upgrading of productive and technological skills. Our proposition is that maquila should also be considered as a strategy for the development of productive capacities, which would imply a different policy approach to this activity.

\footnotetext{
${ }^{1}$ Mexico, four Central American countries (Costa Rica, Guatemala, El Salvador and Honduras) and one Caribbean country (the Dominican Republic).
} 
This paper starts (section II) with the presentation of foreign trade data that reveal the change in the international insertion of those countries in which the maquila industry has risen fast over the past decade or so. Next (section III), the term "maquila industry" is defined and the growth of this industry is described. The third and most important part of this paper (section IV) presents the results of the questionnaire survey. Finally, section V contains some concluding remarks and reflections on policy approaches.

\section{II}

\section{Export performance and composition}

In this chapter we will use the same type of information and methodology as proposed by Fajnzylber (1991). ${ }^{2}$ This methodology illustrates well the drastic change in the international insertion of the economies studied. First, let us consider the market share of the group of selected countries in the total imports of the industrialized countries. Table 1 shows that the selected countries as a group increased their market share between 1989 and 1995 at a pace comparable to successful South-East Asian countries.

Next, we will follow the approach of Fajnzylber (1991) to analyse this export performance in two dimensions: the quality of product composition, and the competitiveness (defined as ability to gain market share) for each product group. Using a rather simple form of shift and share analysis, Fajnzylber presented a matrix inspired by the typology introduced by the Boston Consulting Group. With it, he devised a simple set of indicators which he used as proxies for competitiveness and the quality of the composition of exports.

Algebraically, the indicators are defined as follows. The change in the market share of country $i$ in OECD imports $M$ of product group $j$ between base year $b$ and final year $f$ is represented by:

$$
(M i j(f) / M j(f))-(M i j(b) / M j(b))
$$

If the formula gives a positive result, country $i$ is a "winner" in the OECD market for product group $j$. If negative, then country $i$ lost market share.

\footnotetext{
2 It is necessary to use information on industrialized countries' imports instead of export data, because maquila exports are not always well registered in the latter sources.
}

\begin{tabular}{|c|c|c|c|}
\hline Year & Latin America & $\begin{array}{c}\text { Asian } \\
\text { Tigers }^{a}\end{array}$ & $\begin{array}{c}\text { Mexico, Central } \\
\text { America and } \\
\text { the Dominican } \\
\text { Republic }\end{array}$ \\
\hline 1977 & 5.21 & 6.52 & 1.47 \\
\hline 1984 & 6.16 & 8.34 & 2.32 \\
\hline 1989 & 4.61 & 9.68 & 1.74 \\
\hline 1995 & 4.97 & 12.66 & 2.48 \\
\hline
\end{tabular}

Source: ECLAC, CANPLUS data base.

${ }^{\mathrm{a}}$ South Korea, Hong Kong, Taiwan and Singapore.

The change in product share for each product $j$ in total OECD imports may be expressed as:

$$
(M j(f) / M(f))-(M j(b) / M(b))
$$

If the second formula gives a positive value, this means that imports of product group $j$ grew faster than total imports, so that it may be called a product group with "dynamic demand growth", or simply a "dynamic product". In contrast, a negative value indicates a "stagnant product". It may be noted that Fajnzylber implicitly assumed a positive correlation between "dynamic products" and "technology-intensive" or "new" products. The exercise can be shown in a two-by-two matrix, with formula 1 on the vertical axis and formula 2 on the horizontal axis (figure 1.)

The sum total of all products in all four categories for country $i$ equals the total exports of that country to the OECD market $(M i)$. Now two indicators may be calculated. 
FIGURE 1

\section{The competitiveness matrix}

\begin{tabular}{|c|c|}
\hline $\begin{array}{c}\text { Declining Stars (DS) } \\
\text { Stagnant products in which country } i \\
\text { gains market share }\end{array}$ & $\begin{array}{c}\text { Rising Stars (RS) } \\
\text { Dynamic products in which country } i \\
\text { gains market share }\end{array}$ \\
\hline $\begin{array}{c}\text { Retreats (R) } \\
\text { Stagnant products in which country } i \\
\text { loses market share }\end{array}$ & $\begin{array}{c}\text { Lost Opportunities (LO) } \\
\text { Dynamic products in which country } i \\
\text { loses market share }\end{array}$ \\
\hline
\end{tabular}

TABLE 2

Efficiency and positioning of selected countries, 1979-1988 and 1989-1995 (Percentages)

\begin{tabular}{lccc}
\hline Country & Years & Efficiency & Positioning \\
\hline Mexico & $1979-1988$ & 83 & 64 \\
& $1989-1995$ & 84 & 65 \\
Guatemala & $1979-1988$ & 39 & 24 \\
& $1989-1995$ & 93 & 71 \\
El Salvador & $1979-1988$ & 8 & 26 \\
& $1989-1995$ & 92 & 94 \\
Honduras & $1979-1988$ & 41 & 24 \\
& $1989-1995$ & 81 & 80 \\
Costa Rica & $1979-1988$ & 94 & 38 \\
& $1989-1995$ & 94 & 41 \\
Dominican & $1979-1988$ & 74 & 60 \\
Republic & $1989-1995$ & 86 & 80 \\
\hline
\end{tabular}

Source: ECLAC, CANPLUS data base.

The ratio $(\Sigma R S+\Sigma D S) / M i$ may be considered an indicator of competitiveness, given that it reflects the percentage of total export value of products in which country $i$ gains market share. Fajnzylber called this "efficiency", and it is a proxy for revealed "competitiveness".

The ratio $(\Sigma R S+\Sigma L O) / M i$ may be considered an indicator of the quality of the product composition of exports, given that it reflects the percentage of total export value consisting of dynamic products. Fajnzylber called this "positioning". Both the efficiency and the positioning indicators may vary in theory between 0 and 100 . The efficiency indicator is 0 when the country has lost market shares in all products with which it participated in OECD imports; and is 100 if it gained market shares in every exported product. The positioning indicator will be 0 if all product markets in which a country participated grew less than the growth of total OECD imports, and it is 100 if all product markets grew above average.

Table 2 presents both the 1979-1988 period (Fajnzylber 1991) and the update to 1995 made for this article. It shows that Mexico and the Dominican Republic $^{3}$ already scored high on both indicators in 1988 , and in the subsequent period, up to 1995 , these countries improved slightly on their already good performance. Costa Rica was also already a "winner" country in 1988, more because of its competitiveness ( $94 \%$ of total exports was in products in which Costa Rica gained market shares) than because of good positioning. ${ }^{4}$ Indeed, "stagnant" products were the mainstay of Costa Rican exports in the second period too. In all three countries, the maquila industry started to grow early in the 1980s, which explains a good deal of the good performance indicators in 1988 .

A dramatic shift can be observed in the situation of the other three Central American countries. From being among the world's worst export performers in the 1980s, all three countries advanced to a place among the best performers. Not only did they displace competitors from the product markets in which they participate, but their export product groups are in dynamic demand (United States imports of these products grow faster than average).

\footnotetext{
${ }^{3}$ With regard to the Dominican Republic, see for example Mortimore, Duthoo y Guerrero (1995)

${ }^{4}$ Mortimore and Zamora (1998) offer detailed information on Costa Rican apparel exports.
} 
Will this impressive performance, both in terms of increased market shares and of improved product composition of exports, lead to sustainable development? It may, in the view of ECLAC, if it is based on technical change and productivity increases. This paper analyses in particular the contribution to technical change made by maquila exports. In order to show the particular importance of such exports, the following tables present data on maquila exports as a percentage of total exports for Mexico (table 3) and Central America and the Dominican Republic (tables 4 and 5). The Mexican statistics differentiate maquila exports from other exports, and the percentage increased from $11-15 \%$ at the beginning of the 1980 s to around $40 \%$ in the 1990 s. It is clear that such exports have grown significantly faster than other exports.
TABLE 3

Mexico: Maquila exports as a percentage of total exports ${ }^{\text {a }}, 1980-1997$

\begin{tabular}{lccc}
\hline Year & Percentage & Year & Percentage \\
\hline 1980 & 14.0 & 1989 & 35.1 \\
1981 & 13.8 & 1990 & 34.1 \\
1982 & 11.7 & 1991 & 37.1 \\
1983 & 14.0 & 1992 & 40.4 \\
1984 & 16.9 & 1993 & 42.1 \\
1985 & 19.0 & 1994 & 43.1 \\
1986 & 25.9 & 1995 & 39.1 \\
1987 & 25.7 & 1996 & 38.5 \\
1988 & 33.1 & 1997 & 40.9 \\
\hline
\end{tabular}

Source: Banco de México, http://www.banxico.org.mx

${ }^{a}$ Both maquila exports and total exports are FOB values, and represent the gross production value. Maquila exports are those exports registered under the "Maquila Programme".

TABLE 4

Central America and Dominican Republic: Maquila exports as a percentage of total exports to the United States ${ }^{\text {a }}$, 1990-1997

\begin{tabular}{|c|c|c|c|c|c|c|c|c|}
\hline & 1990 & 1991 & 1992 & 1993 & 1994 & 1995 & 1996 & 1997 \\
\hline Costa Rica & 39.9 & 36.8 & 40.2 & 46.3 & 41.5 & 44.0 & 43.1 & $\ldots$ \\
\hline El Salvador & 30.6 & 58.8 & 52.5 & 57.5 & 70.8 & 79.3 & 82.3 & 81.0 \\
\hline Guatemala & 43.3 & 50.6 & 57.9 & 58.0 & 62.6 & 60.8 & 55.6 & 57.8 \\
\hline Honduras & 43.7 & 43.1 & 51.8 & 59.6 & 71.2 & 81.2 & 72.7 & 70.0 \\
\hline Nicaragua & $\ldots$ & 10.6 & 17.9 & 12.7 & 13.6 & 13.2 & 17.1 & 31.6 \\
\hline Dominican Republic & $\ldots$ & $\ldots$ & 40.4 & 44.5 & 45.7 & $\ldots$ & $\ldots$ & $\ldots$ \\
\hline
\end{tabular}

Source: U. S. Department of Commerce and ECLAC, BADECEL data base.

a United States imports are valued FAS (Free Alongside Ship), and therefore do not include port services, while the countries' exports correspond to their FOB value. Both values represent the gross production value.

TABLE 5

Central America and Dominican Republic: Maquila exports as a percentage of total exports, 1990-1997

\begin{tabular}{|c|c|c|c|c|c|c|c|c|}
\hline & 1990 & 1991 & 1992 & 1993 & 1994 & 1995 & 1996 & 1997 \\
\hline Costa Rica & 21.6 & 20.7 & 23.6 & 26.9 & 23.5 & 23.1 & 23.4 & $\ldots$ \\
\hline El Salvador & 12.6 & 32.9 & 26.7 & 28.1 & 34.7 & 39.6 & 46.3 & 44.5 \\
\hline Guatemala & 22.8 & 27.5 & 32.5 & 34.1 & 34.8 & 32.4 & 31.4 & 32.9 \\
\hline Honduras & 28.0 & 28.4 & 35.5 & 45.1 & 55.8 & 64.1 & 60.7 & 61.1 \\
\hline Nicaragua & $\ldots$ & 2.3 & 4.9 & 5.6 & 6.1 & 5.8 & 8.3 & 17.2 \\
\hline Dominican Republic & $\ldots$ & $\ldots$ & 36.2 & 40.4 & 41.6 & $\ldots$ & $\ldots$ & $\ldots$ \\
\hline
\end{tabular}

Source: U. S. Department of Commerce and ECLAC, BADECEL data base. 


\begin{tabular}{|c|c|c|c|c|}
\hline \multicolumn{5}{|c|}{$\begin{array}{l}\text { Mexico, Central American countries and the Dominican Republic: } \\
\text { Shares in selected import markets } \\
\text { (Percentages) }\end{array}$} \\
\hline & 1979 & 1984 & 1989 & 1998 \\
\hline \multicolumn{5}{|c|}{ Market shares in North American imports ${ }^{a}$} \\
\hline Mexico & 3.56 & 4.86 & 4.74 & 6.78 \\
\hline Costa Rica & 0.16 & 0.14 & 0.17 & 0.23 \\
\hline El Salvador & 0.16 & 0.11 & 0.05 & 0.09 \\
\hline Guatemala & 0.17 & 0.12 & 0.12 & 0.18 \\
\hline Honduras & 0.17 & 0.12 & 0.09 & 0.16 \\
\hline Dominican Republic & 0.27 & 0.25 & 0.28 & 0.38 \\
\hline Central America + Dominican Republic & 0.92 & 0.74 & 0.72 & 1.03 \\
\hline \multicolumn{5}{|c|}{ Market shares in European imports } \\
\hline Mexico & 0.14 & 0.60 & 0.24 & 0.19 \\
\hline Costa Rica & 0.08 & 0.04 & 0.04 & 0.05 \\
\hline El Salvador & 0.05 & 0.03 & 0.01 & 0.02 \\
\hline Guatemala & 0.08 & 0.03 & 0.02 & 0.02 \\
\hline Honduras & 0.04 & 0.03 & 0.02 & 0.02 \\
\hline Dominican Republic & 0.03 & 0.02 & 0.02 & 0.02 \\
\hline Central America + Dominican Republic & 0.27 & 0.15 & 0.11 & 0.13 \\
\hline \multicolumn{5}{|c|}{ Market shares in Japanese imports } \\
\hline Mexico & 0.43 & 1.53 & 0.83 & 0.46 \\
\hline Costa Rica & 0.01 & 0.01 & 0.01 & 0.01 \\
\hline El Salvador & 0.09 & 0.03 & 0.01 & - \\
\hline Guatemala & 0.13 & 0.04 & 0.02 & 0.03 \\
\hline Honduras & 0.03 & 0.04 & 0.04 & 0.04 \\
\hline Dominican Republic & 0.01 & 0.01 & 0.02 & 0.01 \\
\hline Central America + Dominican Republic & 0.28 & 0.13 & 0.10 & 0.09 \\
\hline
\end{tabular}

Source: ECLAC, CANPLUS data base.

${ }^{a}$ The United States and Canada.

National data for Central America and the Dominican Republic do not incorporate maquila exports. United States import data do, but information is available only from 1990 onward (due to the introduction of the Harmonized System). By deducting from the United States imports originating in Central America and the Dominican Republic the exports to the United States registered in the national data $^{5}$, an approximation of the maquila exports of those countries can be obtained. Table 4 shows that maquila exports from El Salvador and Honduras account for $70-80 \%$ of total exports to the United States, a percentage that has increased sharply in the 1990s, while maquila exports from Costa Rica, Guatemala and the Dominican Republic account for around 50\%. As a

${ }^{5}$ According to ECLAC's BADECEL data base. percentage of total exports to the world (table 5), maquila exports amount to as much as $61 \%$ in the case of Honduras, and close to $50 \%$ in El Salvador and the Dominican Republic. ${ }^{6}$

Finally, table 6 shows the market shares of Mexico, the Central American countries and the Dominican Republic in the North American market (the United States and Canada), Europe and Japan. The rise in maquila exports accounts for the notable increase in market shares in the North American market in the 1990s, whereas market shares in Europe and Japan remained virtually unchanged. Their striking export performance was therefore mainly based on their exports to the United States, and in particular on the exports from maquila industries to that market.

\footnotetext{
${ }^{6}$ It is generally accepted that maquila exports embody less local raw materials than "non-maquila" exports. Consequently, the contribution of the value added in maquila exports to total export added value would be less than the percentages shown in tables 3,4 and 5 .
} 


\section{III}

\section{The maquila industry: origin and evolution}

As demonstrated above, the increase in market shares achieved by the selected countries is largely the result of the "maquila industry". But what precisely is maquila? The dictionary says that it is a word of Arabic origin, meaning the portion of grain or oil a miller receives as payment for the milling. In broader economic terms, it would be an activity in which the owner of the raw material hires the owner of the capital good and his labour force to perform a production process, the payment being a fixed percentage of the processed product.

In present-day Mexico, the term "maquila" is associated with a type of economic activity that was first made possible by the Programa de Industrialización Fronteriza (Border Industrialization Programme). This programme was adopted in 1965 to provide employment for approximately 200000 Mexican labourers who had to return from the United States because of the ending of the Braceros Program, which had provided them with temporary employment in the United States in times of labour shortage, especially during the Second World War and the Korean War.

The Border Industrialization Programme allowed tariff-free imports of capital goods and inputs, for export of the finished product. It perhaps resembles the old notion of maquila in that Mexico offers its territory and labour force to a foreign entrepreneur who provides inputs and takes back the processed product. It was essentially a programme to attract foreign direct investment of United States origin for export-oriented assembly operations along the Northern Border. As such, it was an important departure from prevailing import-substitution policies. In 1971 the legislation was modified to allow maquila industries to settle in coastal areas and cities in the interior of the Republic.

The exemptions from duty offered by Mexico in respect of foreign direct investment establishing assembly operations for re-export were complemented by the tariff treatment the assembled products received in the United States. Since 1930 the United States Tariff
Schedule had included item No. 806.30, under which certain metal products manufactured with raw material of United States origin could be re-imported into the United States, paying the applicable tariff only on the value added abroad. This provision was established to facilitate operations between firms in the United States and Canada. Later item 807.00 was added, applicable to goods processed abroad with materials of United States origin. This provision facilitated the operations abroad of United States transnational firms.

Central America and the Dominican Republic followed a different approach from that adopted by Mexico to attract foreign direct investment for the establishment of assembly operations for export, but the aim was likewise to take advantage of the item 807.00 import tariff provision. Here, export processing free zones were created following the example of several South-East Asian countries. In these Free Zones, which were State-owned industrial parks, firms were also allowed to import free of duty raw materials, inputs and capital goods for the re-export of the finished product. Some parks also provided buildings and basic services for the assembly operations. With varying success, all countries except Costa Rica established these Free Zones in the early 1970s. Costa Rica used a special tariff regime to allow the establishment of assembly activities for export.

The crisis of the early 1980s led to profound changes both in the economic environment surrounding the maquila industry and in the legal framework in which it operated. From being an exception in an otherwise inward-oriented policy framework, the export-oriented assembly industry became a spearhead in the change towards an export-led development model. The high political priority attached to exports first translated into changes in the legal framework. In 1984 Costa Rica enhanced the fiscal incentives for exports to destinations outside the Central American region; improved the law regulating temporary entrance of goods for re-export, 
Box 1

CENTRAL AMERICA: EVOLUTION OF THE LEGAL FRAMEWORK GOVERNING MAQUILA INDUSTRIES

\section{Initial situation}

Most laws only considered special export promotion programmes.

Only public ownership and administration of free zones was allowed.

Installation of free zones restricted to certain locations.

Only production for export allowed.

FDI restricted to certain activities.

Maquila benefits restricted to certain activities.

\section{Present situation}

Three different regimes are now in place: i) Export processing free zone laws; ii) Temporary entrance laws and iii) Drawback systems.

Ownership and administration of free zones are now open to private capital.

Tendency to allow free zones throughout the national territory; in some countries individual plants can receive free zone status.

Tendency to allow local sales, after paying import duties.

Liberalization and sectoral diversification of FDI.

Maquila benefits open to all export-oriented activities.

Source: Prepared by the authors, and ILO (1996).

and allowed private capital to participate in the ownership and administration of Free Zones. Guatemala and Honduras also introduced legislation in the same year regarding temporary entrance and export-processing free zones. In the Dominican Republic, the liberalization of the exchange-rate regime proved fundamental for the attraction of assembly operations. In many countries this legislation was subsequently revised and enhanced, and the legal framework was fully operational by the beginning of the 1990s. Box 1 resumes the changes in the legal framework.

Another important development in the first half of the 1980s was the creation of private sector institutions to attract foreign direct investment. Cases in point are the Coalición Costarricense de Iniciativas de De-sarrollo (CINDE, Costa Rica), the Gremial de Exportadores de Productos No Tradicionales (GEXPRONT, Guatemala), the Fundación para las Inversiones y el Desarrollo Económico (FIDE, Honduras), the Fundación Salvadoreña para el Desarrollo Económico y Social (FUSADES) and the Consejo para la Promoción de la Inversión (Dominican Republic). In many cases, these institutions received considerable support from the United States Agency for International Development
(USAID), sometimes channeled through its Regional Office for Central America and Panama.

The local fiscal benefits for export-oriented assembly operations and the establishment of supporting institutions came to complement the important privileges of access to the United States market. The Caribbean Basin Economic Recovery Act (CBERA) of 1983 (renewed in 1990) granted to certain countries a unilateral concession of duty-free access to the United States market for a substantial number of products. Apparel was initially excluded, because its access to the United States market is governed by bilateral quota-restrictions under the Multifibre Agreement. Starting in 1986, however, the United States negotiated Special Access Programmes with CBERA countries to facilitate apparel imports. Most importantly, Guaranteed Access Levels were granted to countries in Central America and the Caribbean that gave those countries freer access to the United States market for apparel products made with United States fabric. Mexico, for its part, negotiated with the United States in 1988 a Special Regime for apparel exports, providing for treatment comparable with that given to the CBERA countries. 
In the case of Mexico, the most important legal changes concerned the authorization to maquila industries to sell up to $20 \%$ (1983) and 50\% (1989) of their production on the local market. More recently, the North America Free Trade Agreement has gradually raised this percentage, and local sales will be allowed in full by 2001 .

The existence of NAFTA has of course made the benefits of the Mexican maquila programme less significant for exports to the United States market, because most tariffs immediately dropped to zero and others were gradually reduced. This does not mean that assembly operations have become less attractive. In the apparel industry in particular, NAFTA meant quota-free access and significantly lower import tariffs for exported products of Mexican origin. Furthermore, transport and telecommunication services and immigration facilities for businesspeople were improved. Maquila industries may, however, take other options into account instead of the Maquila Programme. The PITEX programme is another exportpromotion scheme that is increasingly used for assembly operations for export (SECOFI, 1996). It was created for domestic export-oriented firms and also allows duty-free imports of raw materials and capital goods. Unlike the Maquila Programme, it offers no exemption from asset tax, but it does include a drawback mechanism, under which firms can secure the return of import duties paid on inputs for exported goods.

Fiscal benefits in Caribbean Basin countries, including Mexico7, the establishment of supporting institutions for the attraction of foreign direct investment, privileged access to the United States market and the competitive pressure on United States firms have provided the setting for explosive growth of exportoriented assembly operations.

It has been noted, in the literature on Mexico, that the character of maquila operations has changed over time. ${ }^{8}$ The changes refer to organizational systems and human resource management, the importance of quality, and technological changes. The so-called first-generation maquila plants were plants based on the intensification of manual operations, more concerned with volume than with quality. Their presence predominated until the early 1980s. In contrast, second-generation plants needed the ability to respond quickly to changes in demand for products with short life-cycles and higher quality standards (Carrillo, Mortimore and Estrada (1998)). New technologies were introduced as well as new forms of organization of the production process and changes in human resource management. Production lines were automated, workers had to perform multiple functions, and the proportion of engineers and technicians increased. This is the type of maquila plants that predominate at present. A third generation of maquila plants has also been observed, in which knowledge-intensive activities of product development and design are performed by Mexican engineers with relatively lower salaries. Until now, these cases are very exceptional.

At this point, it seems clear that there is no internationally valid clear-cut definition of maquila industries, and therefore there is no uniform data source on the growth and characteristics of the industry. Mexico uses its own definition, grants maquila status to certain plants and operations and collects statistical information accordingly. In the countries of Central America and the Caribbean, information exists on firms in Export Processing Free Zones and firms qualified to receive export promotion benefits and drawback rights, while from the United States standpoint, the information on United States imports may shed light on the development of the industry.

Maquila exports from Mexico have grown by close to $20 \%$ per year between 1983 and $1997 .{ }^{9}$ Growth rates were particularly strong in 1987 (26\%) and 1988 (43\%). Employment in maquila industries grew in the same period at an annual rate of $13 \%$. In 1997, 2867 plants employed directly almost 940000 workers (figure 2). The increase in the number of plants and jobs has recently been particularly marked outside the border zone.

Between 1988 and 1997, the percentage of total employment in maquila operations represented by the

\footnotetext{
7 See Mortimore and Peres (1998) for some interesting comments on policy competition.

8 See Carrillo and Hualde (1997), Mertens and Palomares (1988), Wilson (1990), and Brown and Domínguez (1989).
}

\footnotetext{
${ }^{9}$ Calderón, Mortimore and Peres (1995) analyse the growth of Mexican exports.
} 
FIGURE 2

Mexico: Employment in the maquila industry

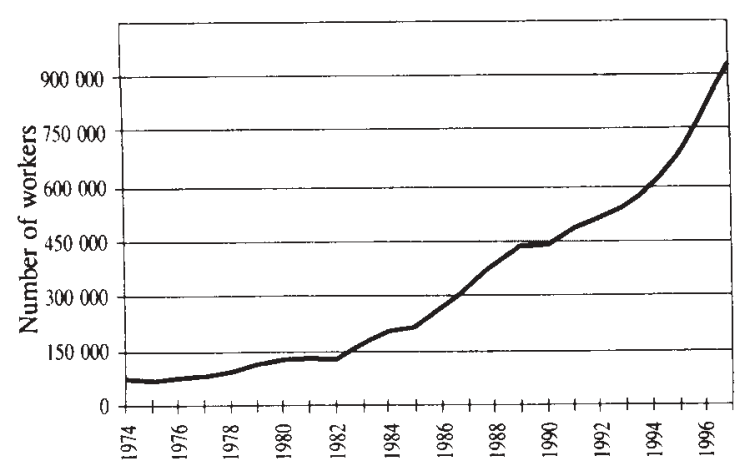

assembly of electrical and electronic products and components went down from $40 \%$ to $34 \%$. Components for automotive vehicles have continued to account for $20 \%$ of such employment, while apparel products have increased their share from $9 \%$ in 1988 to $20 \%$ in 1997 .

Local value added of maquila exports went down from 37\% of Gross Production Value in 1974 to only $20 \%$ in 1997. Local procurement of direct inputs continues to be negligible. Wages, which are the main component of local value added, reduced their share in GPV from $23 \%$ in 1974 to $10 \%$ in 1996 (figure 3). This reveals the trend towards more capital-intensive sectors and production techniques, as well as the fall in real wages (Banco de México, various years; INEGI, various years).

It has not been possible to construct time series on exports and employment for the Central American countries. In 1996, some 800 plants provided close to 250000 direct jobs, according to Gitli (1997). In contrast to Mexico, the vast majority of maquila plants in Central America are devoted to apparel products. Some electrical and electronic maquila firms exist, especially in Costa Rica. This sector received a considerable boost from the establishment of a microprocessor assembly plant early in 1998.

Table 7 shows the origin of capital; it is interesting to observe the presence of Korean-owned plants, especially in Guatemala, and other Asian (Taiwan) plants in Nicaragua. The presence of Asian capital is mainly explained by the quota restrictions on apparel
FIGURE 3

Mexico: Shares of added value and wages in the gross value of production

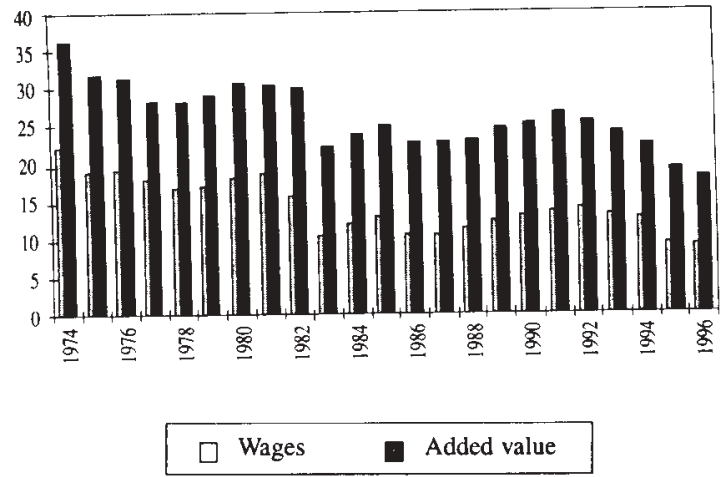

exports to the United States from the Asian countries themselves. There is also a significant presence of local capital in maquila industries, especially in El Salvador, where the law permits the granting of freezone status to individual plants (Predios Fiscales). In Costa Rica, which is the country where maquila plants were first established, the predominance of US-owned firms is evident.

In the Dominican Republic, maquila exports and employment grew fast from 1985 onward. By 1996, 434 plants in 36 free zones exported a total value of US\$ 2.8 billion and employed directly 165000 workers. Almost two-thirds of total maquila exports consist of apparel products.

In short, in the selected countries close to 4000 plants classified as "maquila industries" provided in 1996 close to 1.5 million direct jobs.

Another way of gaining an approximate picture of the evolution of maquila industries in the countries considered is to take a look at United States imports for the main product group involved: apparel products (table 9). It should be noted that these data do not necessarily coincide with what are considered to be maquila industries in the countries of origin.

Whereas in 1990 only 9\% of all United States apparel imports originated in the selected countries, eight years later this figure had increased to well over $26 \%$. In current dollars, apparel exports from these countries to the United States expanded from US\$ 2.1 billion to US\$ 12.1 billion. Another revealing feature of table 9 concerns the tariff applied. The 
TABLE 7

Central America: Origin of capital, number

of plants and employment

\begin{tabular}{|c|c|c|c|c|c|c|c|}
\hline \multirow{2}{*}{ Country } & \multirow{2}{*}{ Plants } & \multicolumn{5}{|c|}{ Origin of capital } & \multirow{2}{*}{ Employmen } \\
\hline & & Local & United States & Korea & Other Asia & Other countries & \\
\hline Costa Rica & 189 & $39(21 \%)$ & $113(60 \%)$ & $4(2 \%)$ & $3(2 \%)$ & $30(16 \%)$ & 47972 \\
\hline El Salvador & 190 & $123(65 \%)$ & $20(11 \%)$ & $16(8 \%)$ & $12(6 \%)$ & $19(10 \%)$ & 42000 \\
\hline Guatemala & 220 & $95(43 \%)$ & $20(9 \%)$ & $96(44 \%)$ & $4(2 \%)$ & $5(2 \%)$ & 61800 \\
\hline Honduras & 174 & $56(32 \%)$ & $62(36 \%)$ & $37(21 \%)$ & $17(10 \%)$ & $2(2 \%)$ & 78583 \\
\hline Nicaragua & 19 & $3(16 \%)$ & $6(32 \%)$ & $3(16 \%)$ & $6(32 \%)$ & $1(5 \%)$ & 13000 \\
\hline Total region & 792 & $316(40 \%)$ & $217(28 \%)$ & $156(20 \%)$ & $42 \quad(5 \%)$ & $57 \quad(7 \%)$ & 245355 \\
\hline
\end{tabular}

Source: Gitli (1997).

TABLE 8

Dominican Republic: Export Processing Zones, 1990-1996

\begin{tabular}{|c|c|c|c|c|c|c|c|}
\hline & 1990 & 1991 & 1992 & 1993 & 1994 & 1995 & 1996 \\
\hline Exports (millions of dollars) & 1123.5 & 1415.8 & 1839.3 & 2165.1 & 2453.9 & 2700.1 & 2851.9 \\
\hline Value added (millions of dollars) & 351.7 & 448.1 & 575.7 & 677.7 & 768.1 & 845.1 & 892.6 \\
\hline Number of EPZs & 25 & 27 & 30 & 31 & 32 & 33 & 36 \\
\hline Number of plants & 331 & 357 & 420 & 462 & 476 & 469 & 434 \\
\hline Employment & 130045 & 135491 & 141056 & 164296 & 176311 & 165571 & 164639 \\
\hline
\end{tabular}

Source: National Council of Free Zones.

implicit tariff is calculated as total duties levied divided by total value of imports. In 1990 it showed a rather uniform picture, with tariffs between $17 \%$ and $20 \%$. NAFTA meant the virtual elimination of tariffs for Mexican apparel exports, while the special access provisions for Central America and the Dominican Republic brought the implicit tariffs down to a range of 5\%-10\%. Apparel exports from countries without preferential access to the market continue to pay a substantially higher implicit tariff.

In the Mexican case, maquila exports of car parts and electrical and electronic equipment are substantial. Cars and parts thereof come under tariff heading
87, where Mexico increased its market share from $5 \%$ in 1990 to $13.4 \%$ in 1997 . Implicit tariffs fell from $2.8 \%$ to $0.6 \%$. Electrical and electronic equipment and parts thereof come under heading 84, where Mexico's market share increased from 3.6\% in 1990 to $7 \%$ in 1997 , with implicit tariffs falling from $1.9 \%$ to $0.3 \%$.

All this evidence clearly shows the impressive performance of the maquila industry after the changes in the legal framework, supporting institutions and market access conditions that occurred in the 1980s and 1990s. The next section discusses the industry's impact on technical change in the selected countries. 
FIGURE 4

\section{Dominican Republic:}

\section{Export Processing Zones}

A. Number of plants, 1970-1996

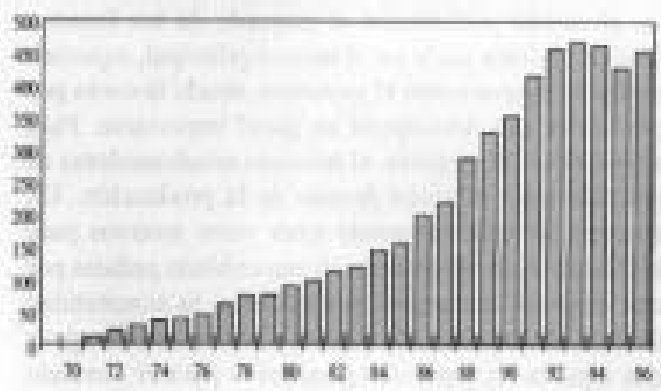

B. Exports, in millions of dollars, 1983-1996

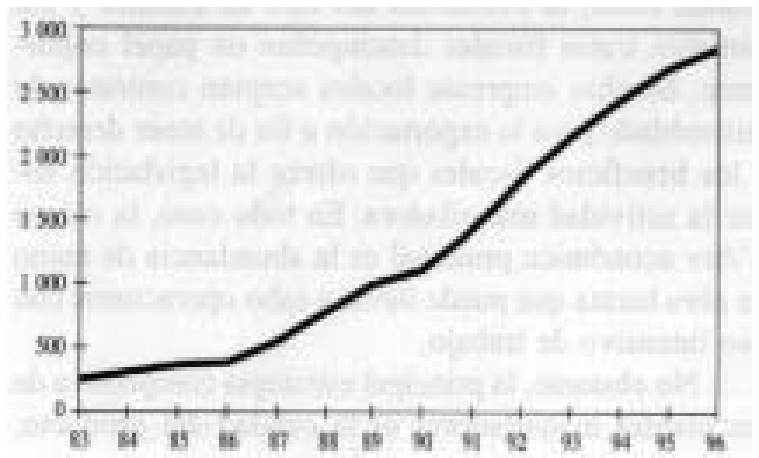

C. Direct employment, 1970-1996 (number of persons employed)

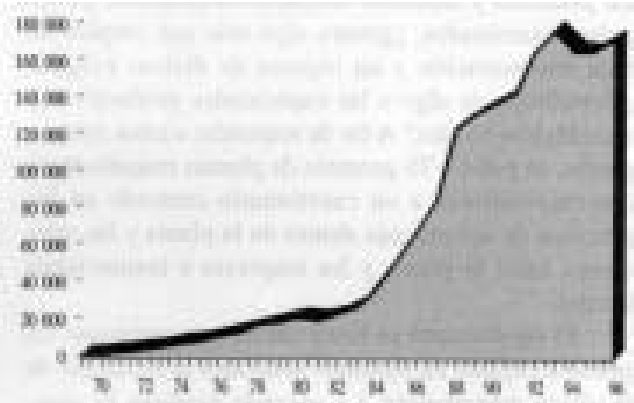

TABLE 9

United States: Imports of apparel products (Tariff chapters 61 and 62 totalized)

\begin{tabular}{lrrrrr}
\hline \multirow{2}{*}{ Country of origin } & \multicolumn{2}{c}{ Market share } & & \multicolumn{2}{c}{ Implicit tariff } \\
\cline { 2 - 3 } \cline { 6 - 6 } & 1990 & 1997 & & 1990 & 1997 \\
\hline Mexico & 1.79 & 11.75 & & 17.12 & 0.70 \\
Guatemala & 0.83 & 2.16 & & 19.41 & 9.85 \\
El Salvador & 0.24 & 2.36 & & 17.88 & 6.54 \\
Honduras & 0.49 & 3.78 & & 19.54 & 5.72 \\
Costa Rica & 1.64 & 1.89 & & 19.78 & 5.12 \\
Dominican Republic & 2.98 & 4.90 & & 19.94 & 5.90 \\
\hline
\end{tabular}

Source: United States Department of Commerce, US Imports of Merchandise (published on CD-ROM), processed using the MAGIC software programme developed by ECLAC.

\section{IV}

\section{Maquila and technical change: results from a questionnaire study}

Does the strong and growing maquila industry in the selected countries generate more than lowwage employment and a little foreign-exchange income? What, if anything, does it contribute to local productive and technological capabilities? To explore these questions, some 75 managers of maquila plants were asked to answer a questionnaire focused mainly on learning processes within the plant and the relations between the plant and local firms and institutions.
The questionnaire was divided into three sections. The first explored in general terms the strategy of the maquila plant. The second explored the situation within the plant regarding human capital formation and research and development activities. The last section investigated the links between the plant and its surrounding environment in terms of relations with other firms, with governments and with local institutions of education and training and technological development. 


\section{Strategies of the maquila plant}

First, the questionnaire asked about the motives behind the existence of the plant. For a maquila plant belonging to a United States-owned corporation, the main motive is the lowering of costs by using cheap labour in the selected countries. For a non-US foreign firm, preferential access to the United States market is usually another main motive, especially in product markets -such as those for apparel- where quotas per country of origin play an important role. For both types of firms, the United States market is virtually the only destination of production. In order for a national entrepreneur to engage in assembly operations ordered by a foreign firm, some other motives may be involved: for example, the rate of return should be higher or less risky than in the case of an investment in production capacity for the domestic market. In this regard, expectations about local demand, the evolution of exchange rates, and different fiscal treatment play an important role. Many local firms take on assembly contracts for export in order to qualify for the fiscal benefits offered under maquila legislation. At all events, the main economic raison d'être is the abundance of cheap labour that can perform labour-intensive operations.

The main competitive strategy of maquila plants is product quality, however. Another element that may give a plant a competitive edge is timeliness. The challenge is to produce the highest quality in the shortest period of time, using the relatively cheap labour force that all the other plants also use. This competitive strategy fits clearly within the description of "secondgeneration maquila industry". An illustration of the quest for quality is that a substantial number of firms interviewed had ISO 9000 certification, and almost all were in the process of applying for it.

Finally, in the section about strategy a question was included which was designed to explore the degree of autonomy of the maquila plant (table 10). The answers shed a clear light on what kind of learning processes may be expected. With the exception of some surprising answers, in general the managers at a maquila plant do not have decision-taking power on i) the procurement of raw material, ii) selection of the end-products, and iii) marketing. If there is a department of procurement at all, it is for the local acquisition of inputs that do not enter directly into the production process. A maquila plant usually does not have a sales department.

Managers at a maquila plant may have a say in the selection of machinery and the financial and investment strategy. They are usually completely responsible for the recruitment and training of personnel and the organization of production. It should be noted that in plants with local capital, managers tend to have a broader range of responsibilities.

\section{Human resources development}

The characteristics of the human resources employed are similar in virtually all the plants visited. Around $80 \%$ of all employees have at most secondary education; virtually no employees do not have at least primary education. Especially in Mexico, the trend is to hire people who have completed their secondary education. Over $50 \%$ of the total employees are between 18 and 24 years of age, while a further third are under 35. In apparel plants, between $60 \%$ and $90 \%$ of all employees are women.

Mexico and Central America: Participation in strategic decisions (Percentages)

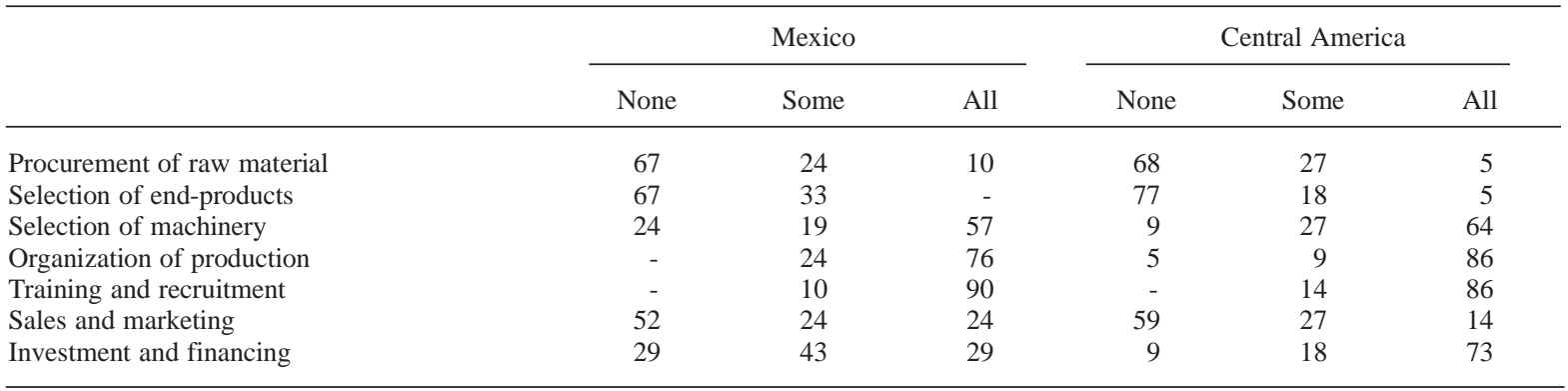

Source: Prepared by the authors. 
Although it may seem far removed from "contributions to local technological capabilities", the training young men and women receive at a maquila plant is a very important matter. For a good many, often with a rural background, it is their first contact with the formal, urban and industrialized world. They receive formal training regarding the firm and their specific job, but also in social habits, hygiene, and so forth. Virtually all firms have continuously programmed courses on quality control, efficiency and cost reduction, and prevention of accidents.

The job-related training received by workers is modest in the sense that they are required to perform only simple tasks, for which a few days of on-the-job training suffice. The learning curve is short, especially in maquila industries outside the apparel sector. A worker may reach normal productivity levels within a week. In some apparel plants, however, the learning curve may be longer.

Formal training is also provided for supervisors and managers. Two important trends became clear during the interviews: the proportion of employees with advanced technical and academic education is increasing, and they are increasingly locals. The greater complexity of production processes accounts for the first trend, while cost-awareness accounts for the second. Local engineers and skilled technical personnel receive courses on training techniques, quality control, teamwork and human resources management. They are in frequent contact with foreign engineers who visit the plant and provide technical assistance, supervision and training. Moreover, local engineers frequently have to visit corporate headquarters and plants in other countries in order to learn in situ about production techniques. This type of interaction seems to be more frequent in fully owned subsidiaries of foreign firms than in maquila plants with national capital. Administrative personnel receive training on strategic planning, leadership, customer satisfaction, fiscal and labour regulations, and other self-improvement courses such as "the seven habits of highly efficient people".

Finally, a comment may be made regarding the contribution of maquila industries to the formation of entrepreneurs: perhaps the one human resource most lacking in underdeveloped countries. Local capital participates significantly in maquila industries. Consequently, a group of national entrepreneurs exists that have both plants for domestic sales and assembly plants for export. The relation with a foreign client allows
TABLE 11

Mexico and Central America: Methods and programmes for the organization of production applied in the maquila firms interviewed

(Percentage of affirmative answers)

\begin{tabular}{lcc}
\hline & Mexico & $\begin{array}{c}\text { Central } \\
\text { America }\end{array}$ \\
\hline Total quality control & 90 & 64 \\
Just-in-time production & 65 & 68 \\
Continuos improvement & 80 & 55 \\
Team work & 75 & 77 \\
Manuals, procedures and internal rules & 90 & 82 \\
Workers' suggestions programmes & 50 & 77 \\
Sharing of technical and economic & & \\
information with workers & 65 & 72 \\
Programmes to increase security & & \\
on the job & 85 & 91 \\
Ergonomic programmes & 55 & 64 \\
\hline
\end{tabular}

Source: Prepared by the authors.

them to stay informed of product and process innovations and to receive technical assistance. The knowledge thus acquired can be transferred to their plants producing for the domestic market, thus generating important productivity gains. The automation of production processes and the introduction of modern organizational techniques are frequently mentioned among the benefits received in this way.

Nevertheless, maquila does not seem to be a very suitable source for upgrading entrepreneurial skills. Only exceptionally have local managers and technical personnel of maquila plants been able to start their own firms. The problem seems to be the absence of a sufficiently aggressive and innovative group of local entrepreneurs and the lack of financial and technological support. Furthermore, the strict requisites of transnational corporations regarding their suppliers represent a barrier to entry into the industry.

The results of the questionnaire study show that the contribution of maquila to technological learning lies in particular in the realm of the organization of production (table 11). Most of those interviewed confirm the use in their plants of modern organizational techniques, such as flexible production, total quality control, just-in-time production, and continuous improvement. Without doubt, the degree of utilization of these techniques is more widespread in maquila plants than in other national firms. Furthermore, these techniques are not just plain copies, because most manag- 
ers confirmed the need to adapt organizational techniques to local conditions and to the idiosyncrasies of the workforce.

In all the countries studied, maquila plants are under pressure to deliver large volumes of the best quality products on time, while keeping production costs in check. This pressure generates a continuous search for the most efficient way of organizing production. New management and organizational systems are introduced all the time, and almost all maquila plants use production teams, quality control programmes, operating manuals and norms, and workers' suggestions programmes.

\section{Technological evolution of production processes in maquila plants}

The contribution of maquila industry to the knowledge about production processes is also important. Second-generation maquila plants use state-of-the-art technology, to be able to meet the quality standards of clients. Technical and supervisory personnel receive constant training in the use of the machinery, and stay on top of technological development. Maquila plants make virtually no contribution to the introduction and development of new products, however: product development remains an activity of corporate headquarters.

At the plants visited in all six countries, an interesting process has been observed in terms of the evolution of the tasks performed. In many cases, an assembly plant starts off with only a limited number of simple assembly operations. When the plant meets the standards of the client, other and more sophisticated parts of the production process are transferred to the plant, and sometimes even the whole production process. After a number of years, the maquila plant may even give feed-back to the corporate headquarters and suggest changes in production processes. In some cases, it has been found that the whole process of testing and adapting a new production line is carried out at the maquila plant. There seem to be two types of reasons for this trend. First, there are those relating to learning processes within the plant: as the quality and efficiency of the labour force increases, the clients in the United States increase their confidence in the capabilities of the maquila plant and entrust it with a broader range of tasks. Second, there are reasons outside the sphere of the plant: there are competitive advantages in having complete manufacturing proc- esses (and even product and process design) concentrated in one location. The need to respond with agility to changes in demand, and the positive effects that arise from the interaction between product and design departments, generate a trend towards geographical concentration of tasks.

In the case of maquila plants in Central America and the Dominican Republic (especially in apparel assembly) this evolution takes the form of a higher degree of integration of production processes and the introduction of more sophisticated machinery. A dual movement can be observed toward "full package production" 10 and automation. Technicians and engineers who were interviewed underlined the importance of being in contact with the complete production process for ensuring a better learning process (Vicens, Martínez and Mortimore, 1998).

In Mexico, four plants were observed to have product design departments, with foreign and local engineers. These departments contribute through the design of small parts of the final product (usually not the more technologically demanding parts). In two plants -one producing television sets and another electric organs- the design of the external structure is done locally. In a third plant, producing air conditioning systems, tubes and connectors are designed locally. Only in a furniture factory is the full design done at the maquila plant.

While these four cases are obviously exceptional, all the plants visited had quality control departments with some technological capabilities. In the apparel sector, product design is carried out closer to the place of final sale, in order to be in direct contact with customers, and the foreign corporation sends patterns and exact product specifications to the maquila plant. Nevertheless, in all countries several cases were found of plants that work with prototypes and perform testing. What happens is that product specifications and operating manuals are received from abroad and tested at the plant, and feed-back reports with recommendations on product specifications and inputs are prepared for discussion with the foreign corporation.

\footnotetext{
${ }^{10}$ In "full package production" the maquila firm orders the fabric and trimmings, and cuts, sews, finishes and packages the product, while the client concentrates on marketing and distribution. In other arrangements, maquila plants only cut, sew, finish and package the product, with the client providing the fabric and accessories.
} 
In Mexico, activities were observed which involved incremental improvements in product specifications and design. More than $50 \%$ of the plants visited reported that they had contributed, albeit sometimes only in minor details, to the product characteristics through, for example, suggestions for the use of different raw materials, recommendations that led to reductions in the use of inputs, modifications that allow easier assembly and better functioning of the final product, and changes in product presentation. In all these incremental improvements, the final decision is not made by Mexican or foreign engineers at the plant, since the suggestions must be submitted to the research and development centres at corporate headquarters, where the final decision is taken.

Generally speaking, at the maquila plant no research and development activities are carried out concerning machinery. The machinery is usually selected by the foreign corporation, and the installation of production lines is carried out, or at least supervised, by foreign engineers. However, local engineers can and do learn from participating in the installation of production lines, and in some cases subsequent production lines are installed by local engineers, without technical assistance from the headquarters corporation.

In most cases, local personnel do perform some maintenance operations, but if a major problem arises, especially with the more sophisticated machines, specialists must come from abroad or parts of machines must be sent to the supplier. If any "innovations" are made to machinery by the maquila plant, they involve peripheral components that speed up the production process. Also, small ergonomic improvements have been introduced by local engineers to adjust the machinery to the size and proportions of Mexican and Central American workers, and some auxiliary tools have been designed and fabricated.

\section{Diffusion of technological learning outside the maquila plant.}

As noted earlier, the weak linkages between the maquila plant and local firms mean that there are no direct processes of transfer of technological capabilities and know-how. If there is some diffusion of the learning processes, it is through the training of the work force, which may improve human resources capabilities in general.

Along the northern border of Mexico, in Costa Rica, and to some extent in the Dominican Republic and Honduras, formal relationships exist between maquila plants and their trade associations, and training institutes and schools. The idea is to improve the preparation of the work force before workers enter maquila plants. In the North Mexican case, the CONALEPs, CECATIs, CETIS, State Universities and the different campuses of the Technological and Higher Studies Institute of Monterrey (ITESM) are clear examples of educational institutes that maintain a strong relation with the maquila industry and define their curricula partly in the light of the needs of those plants. In particular, in Ciudad Juárez there is an active "liaison committee" in which representatives of educational centres and maquila plants discuss the training needs of the future work force. In Costa Rica, most of the plants visited recognized the importance of their relationship with the Costa Rican Technological Institute and the Vocational Training Institute. The installation of a plant the size of INTEL in Costa Rica, with its policy of hiring only people who have a technical degree on top of their secondary education, speak English and are skilled in the use of the Microsoft Office computer programme has naturally shaken the whole educational system. The company has explicit ideas on educational policy in Costa Rica, and works closely with national authorities to improve the quality of the entire system. Most schools and training institutes have introduced changes in their programmes in order to supply human resources for the incipient microelectronics maquila industry.

A special comment is in order regarding locally owned maquila plants. Local firms that engage in assembly operations for foreign clients usually do not devote all their production capacity to these assembly operations, and they maintain production lines catering to domestic demand. Consequently, there may be a transfer of knowledge between the maquila plant and the other production activities of the local firm. The effective transfer of technology through this channel depends on the type of relation with the foreign client, the characteristics of the products assembled, and the similarity between the maquila assembly line and the other production lines.

According to several managers who were interviewed, the technological and productive capabilities of local firms have improved because of the assembly operations and the interaction with foreign specialists of transnational corporations. New products, new production techniques and new forms of organization of the firm and of the production process have been introduced in this way. 


\section{V}

\section{Conclusions}

The central question in this paper is whether maquila industries contribute at all to local technological development. The answer has to be affirmative. Maquila industries employ production techniques close to international best practices: something that can only be said of a small number of local manufacturing plants. Additionally, maquila plants contribute to the formation of human resources and introduce modern concepts of organization and management.

This being said, it remains true that maquila activities are above all intensive in the use of lowskilled labour, of which there is an abundant supply in the Caribbean Basin countries and Mexico. It does not therefore seem appropriate to suggest that maquila could be the type of international insertion that would allow those countries to reach a sustainable growth path with social equity. Its high import content and low local value added limit its multiplier effect on demand, so that its contribution to growth is lower than could be expected from the volume of the activity. If maquila industries in their present form were to multiply and completely dominate the production and export structure, these countries would be specializing in the supply of low-wage labour, and their growth would depend solely on the cost-competitiveness of this production factor. This does not seem to be compatible with a long-run strategy of growth with social equity. In the short run, of course, given the abundant supply of low-skilled labour, maquila industries do contribute positively to social equity, given their impressive capacity to generate employment, especially for the presently unemployed or underemployed poor.

In its present form, the maquila industry does not seem to be an engine of sustainable development with social equity, although its contribution is without doubt a positive one. The road to follow seems to be the transformation of maquila industry into an activity that does not only base its competitiveness on low wages and privileged market access conditions, but also on increasing productivity and a higher value-added content. At the same time, maquila industry could mean a transfer of technology to the economy as a whole, although the diffusion of knowledge acquired through maquila to other sectors of the economy is still limited, because of the strong dualism between maquila and domestic production, and also because of the limited absorption capacity of the domestic economies.

Furthermore, there are a number of external obstacles that hinder a stronger contribution of maquila industry to sustainable development with social equity. In the first place, transnational corporations still maintain the policy of transferring "ready-made" technologies, without transferring technological research and development activities. In the second place, transnational corporations do not stimulate procurement of local inputs, either because the corporation is vertically integrated, or because they have an established network of suppliers that it is difficult for local firms to enter, because of the certification process for suppliers that requires time, money and technological capabilities those firms lack.

The change from apparel maquila activities to the so-called "high-technology" maquila industry that is underway in Costa Rica does not seem to be a sufficient means for maquila to become a mayor source of technological progress. The questionnaire study clearly showed the limitations of microelectronics maquila in this regard. Firstly, manual assembly tasks predominate, as well as manual control of machinery and visual quality inspection. Second, technology is transferred "ready to use", without local research and development. Third, no microelectronics firms exist in the local economy that could absorb personnel who acquire increased knowledge through maquila. Fourth, the lack of local content limits the diffusion of knowledge. Finally, the rapid pace of technological development in microelectronics tends to nullify the possibilities of local managers becoming agents of "endogenization" of the tecnology.

If the above is a fair picture of what maquila industries contribute to technological progress in the selected countries, three questions remain to be answered. First, if maquila industries will evolve from an activity highly intensive in the use of low-skilled and low-paid labour to other activities more intensive 
in the use of productive knowledge and capabilities; second, if technological progress in maquila industries spreads throughout the domestic economy; and third, how public policies may help to obtain affirmative answers to the first two questions.

With regard to the evolution of maquila industries, the contrast between national cases provides certain answers. The maquila industry has existed in Mexico for over 30 years, and its production structure differs notably from maquila in Central America and the Dominican Republic. In Mexico, most plants are in high-technology sectors such as autoparts, electrical appliances and microelectronic goods. While it is true that only the labour-intensive parts of the production processes are performed in Mexico, it is nevertheless true that these firms hire increasingly qualified personnel. Only rarely do they employ workers with just primary education, and the proportion of local technicians and engineers is increasing. A similar pattern is observed in Costa Rica with the entry of important plants in the microelectronics sector.

The pressure maquila activities exert on the local labour market is increasing real wages. This, in turn, requires the maquila industry to evolve toward activities of a higher value-added content that will allow higher wages. However, this evolution will not be possible without effective support from the national systems of human resource formation and institutions that further technological development.

In sum, the evolution of maquila industries toward activities that require higher qualifications of the work force is possible, as shown by the Mexican case, and it will be unavoidable when pressures on the labour market push real wages upward, as shown by the Costa Rican case. But it will not occur automatically, and even less so in countries that do not have supporting institutions for such development.

With respect to the second question, the spread of technical change throughout the domestic economy is limited because of three circumstances. First, because the technical progress in maquila industries is itself of a limited nature; second, because the linkages between maquila and the domestic economy are weak; and third, because the absorption capacity of the domestic economies is limited.

With regard to the issue of human resource formation, the main question concerns the usefulness of the knowledge thus acquired in other firms and other functions, which would be an indicator of the possi- bility that the abilities could be used in other economic activities. Here a distinction may be drawn between apparel maquila activities and other types of maquila. In the apparel sector, the abilities acquired by the workforce are widely used in domestic activities and also in local apparel firms. There is some evidence that people who have learned production techniques in maquila plants start small tailoring workshops for the domestic market. In other maquila activities, however, the type of know-how acquired seems to be so specific that its utility outside the maquila plant is very limited. In general, maquila firms tend to prefer to hire people without previous experience because of their greater willingness to learn specific job-related skills required by the plant.

In contrast, the knowledge acquired by local technicians and engineers is more likely to be useful to other firms, even if they are not in the maquila business. The demand for those human resources is so strong that frequently technicians and supervisors are attracted away from maquila firms by offering them higher salaries and better fringe benefits.

Some knowledge regarding production processes may be transferred to other economic activities, even outside the maquila industries, especially in the apparel sector. The diffusion of knowledge does not seem to be of such a magnitude as to affect the level of productivity of manufacturing industry as a whole, however. The reason for this may be that, except in the case of the apparel industries, the other sectors in which maquila industries operate are not represented in the domestic economy. Another factor may be that the level of quality requirements in domestic industries is lower than in maquila activities. Finally, domestic firms may have less financial possibilities for acquiring state-of-the-art machinery and do not have the same access to technical assistance.

A second factor that limits the spread of technical change in the domestic economy is the low level of linkages between maquila industries and local firms and institutions. Because of the nature of assembly operations and the legal framework in which they developed, maquila industries import virtually all raw materials and inputs used in the production process and therefore do not develop local suppliers. Because the plants export almost all that they produce, there is also no direct competition with local plants on the domestic market: something that would oblige local firms to catch up with the technological standards of the maquila industries. Some linkages 
exist with local human resource formation institutions, but virtually no relations exist with institutions engaged in technological research and development.

The third aspect -the low absorption capacity of domestic firms for the technological progress generated in maquila industries- requires an analysis which is outside the scope of the present paper. It may be noted that there is a difference between Mexico and Costa Rica, on the one hand, and the Central American countries and the Dominican Republic on the other. The level of development of human resources and of the local institutions supporting technological progress is significantly higher in the first two countries.

This leads to the answer to the third question, regarding policies to promote the evolution of maquila plants toward activities that are more knowledge-intensive, as well as to promote the linkages between maquila plants and local suppliers. Our main finding is that maquila industry needs to be seen as an integral part of strategies for the upgrading of productive development. In the past, maquila was exclusively considered to be part of employment policies. Later it was also seen as a foreign-exchange earner. Until now, it has not been regarded as a strategy for the development of local productive capabilities.

This may perhaps explain the existing duality between the productive specialization in maquila industries and in the rest of the economy. The element of promotion of productive linkages was simply not considered relevant at the time the promotion schemes were devised. But the maquila industry nowadays is a phenomenon of such a magnitude that it undoubtedly forms part of the production structure of the selected countries.

To consider maquila as an integral part of a strategy of production development does not mean increasing government interference to a level that would hinder the growth of the industry. Clearly, in the Mexican border zone local governments and maquila organizations interact for mutual benefit. In any case, production development strategies in Latin America do not discriminate nowadays beforehand between production sectors. They concentrate instead on the improvement of human resources, strengthening of institutions to support technological development, investment in infrastructure, and financial support programmes. In these policy areas, the interests of maquila industries should be taken into account in the same way that those of other production sectors already are at present. Only by strengthening local productive and technological capabilities in a general sense can maquila industries be made to evolve successfully towards activities of a higher local value-added content, with stronger linkages between the maquila sector and the domestic economy and enhanced capacity of the domestic economy to absorb the know-how generated.

One particular aspect deserves special attention, and that is the tax regime for maquila industries and local firms. The essence of maquila programmes and export-processing free zones was exemption from import taxes. Today, domestic exporting firms may also receive those benefits, through drawback schemes. In this respect, they operate under roughly the same conditions. However, local efforts to attract foreign direct investment have also included the granting of tax holidays regarding other corporate taxes, notably profit tax (in Central America) and asset tax (in Mexico). At present, the trend is to allow maquila industries to sell on the local market too, after paying import taxes, which are increasingly negligible. When they do this, however, maquila industries still retain the privilege of not paying other corporate taxes, and this difference in tax regimes encourages domestic firms to set up shop in free zones or otherwise apply for maquila status. If maquila firms are to be considered equal to other manufacturing industries, these differences in tax regimes should be eliminated.

(Original: English) 